\title{
SZEMANTIKUS SZEREPEK AUTOMATIKUS CÍMKÉZÉSE TERMÉSZETES SZÖVEGEKBEN
}

\section{SEMANTIC ROLE LABELING ON NATURAL TEXTS}

\author{
Subecz Zoltán ${ }^{1}$, Nagyné Csák Éva ${ }^{2}$ \\ ${ }^{1}$ Informatika Tanszék, GAMF Műszaki és Informatikai Kar, Neumann János Egyetem, Magyarország \\ ${ }^{2}$ Gazdasági szaknyelvek Tanszék, Kereskedelmi, Vendéglátóipari és Idegenforgalmi Kar, Budapesti \\ Gazdasági Egyetem, Magyarország \\ https://doi.org/10.47833/2020.1.CSC.001
}

\section{Kulcsszavak: \\ információkinyerés \\ adatbányászat \\ szövegbányászat \\ gépi tanulás \\ eseménydetektálás}

\section{Keywords:}

information extraction

data mining

text mining

machine learning

event detection

\section{Cikktörténet:}

Beérkezett 2019. december 10.

Átdolgozva 2020. január 7.

Elfogadva 2020. január 20.

\begin{abstract}
Összefoglalás
Jelen tanulmányunkban bemutatjuk gazdag jellemzőtéren alapuló gépi tanuló megközelítésünket, amely automatikusan képes magyar nyelvü szövegekben szemantikus szerepek címkézésére függőségi elemző alkalmazásával. Munkánkban a vállalati vásárlások, tulajdonváltozások keretével foglalkoztunk. Jellemzőkészletünkben felszíni, morfológiai és a függőségi elemzés alapján kinyert jellemzőket használtunk fel. Ezen alapjellemzőket kiegészítettük a jellemzökböl számolt statisztikai arányokkal is. Megvizsgáltuk, hogy a modell hogyan teljesit egy gyakori célszóra önállóan, és a célszavak keretekbe összefoglalt csoportjára is.
\end{abstract}

\begin{abstract}
In this study we introduce a machine learning-based approach that can automatically label semantic roles in Hungarian texts by applying a dependency parser. In our study we dealt with the areas of purchases of companies and news from stock markets. For the tasks we applied binary classifiers based on rich feature sets. In this study we introduce new methods for this application area. Having evaluated them on test databases, our algorithms achieve competitive results as compared to the current English results.
\end{abstract}

\section{Bevezetés}

Az Információkinyerés egyik fontos feladata a névelemek felismerése mellett az események detektálása $[15,16]$. A szövegekben lévő események felismerése, analizálása, és hogy hogyan viszonyulnak egymáshoz időben, fontos a szöveg tartalmának megismerésében. Az események detektálása mellett fontos azok szemantikus kapcsolatainak, vagy szemantikus szerepeinek megtalálása is (szemantikus szerepek címkézése, Semantic Role Labelling, SRL). Az események és azok szemantikus szerepeinek detektálását a természetes nyelvfeldolgozás sok területén lehet hasznosítani. Például az összegzéskészítés, gépi fordítás és a válaszkeresés területein.

Munkánkban a szemantikus szerepek címkézésével foglalkoztunk. Ez a szemantikus kapcsolatok azonosítását jelenti egy szemantikus kereten belül (semantic frame). A keretek eseményeket írnak le azok szereplőinek szintaktikai és szemantikai megkötésein keresztül. Munkánkban a vállalati vásárlások, tulajdonváltozások keretével foglalkoztunk.

\footnotetext{
${ }^{1}$ Kapcsolattartó szerző: subecz.zoltan@gamf.uni-neumann.hu
} 
A szemantikus szerepek címkézése napjainkban a természetes nyelvfeldolgozás (NLP) egyik legdinamikusabban fejlődő területe. Angol nyelvü szövegekre általában konstituensfa alapú szintaktikai elemzőt használnak az elő-feldolgozásnál az angol nyelv erősen konfiguratív tulajdonsága miatt, ahol is a legtöbb mondatszintű szintaktikai információt a szórenddel fejeznek ki. Ezzel ellentétben a magyar nyelv gazdag morfológiával és szabad szórenddel rendelkezik. A függőségi fákkal dolgozó elemzők különösen jól használhatóak szabad szórendü nyelvek elemzésére, így a magyarra is, ezek ugyanis könnyebben teszik lehetővé az egymással nem szomszédos, de összetartozó szavak összekapcsolását is. Ezért mi a magyar nyelvű szövegeinkre függőségi fákkal dolgozó elemzőt használtunk a Magyarlanc programcsomag segítségével [20]. A szövegek szavakra bontására, a szavak morfológiai elemzésére, szófaji egyértelmüsítésére, és mondatok függőségi nyelvtan szerinti szintaktikai elemzésére is ezt alkalmaztuk.

A függőségi nyelvtan (Dependency grammar) a modern szintaktikai elméletek egy olyan csoportja, amelyik a függőségi kapcsolatokon alapul (ellentétben a konstituensfa-alapú kapcsolatokkal). A függőségi reprezentáció a szavakat a közöttük lévő kapcsolatok alapján kapcsolja össze és egy fastruktúrában ábrázolja. A fa minden csomópontja egy szót reprezentál, a gyerekcsomópontok azon szavak, amelyek függnek a szülöcsomóponttól és az ágat a kapcsolattal címkézzük. A fö ige a gyökér elem. Ha egy kapcsolati-egység több szót tartalmaz, akkor ezek a szavak egy részfát alkotnak a fő fán belül.

A mondat szavai közt fennáló kapcsolatok reprezentálásának másik elterjedt módja a konstituens (constituent) fák alkalmazása. Ebben egy konstituens egy szó, vagy szavak csoportja, ami egy egységként funkcionál egy hierarchikus struktúrán belül. Szavak csoportjai (eredeti sorrendben) egységeket alkotnak. A frázisok (phrase) több mint csak szavak csoportja. Olyan szavak csoportja, amelyek együtt töltenek be egy speciális szerepet a mondaton belül. Ezen szócsoportok együtt mozgathatóak, vagy helyettesíthetőek, miközben a mondat jól olvasható és nyelvtanilag helyes marad. A konstituens reprezentáció célja a mondatok ilyen rész-frázisokra való bontása. A természetes nyelvekben a frázisok egymásba ágyazva helyezkednek el, így a mondatokat fastruktúrában tudjuk ábrázolni.

A szerepek a legegyszerübb esetekben a célszó szintaktikai kapcsolatai voltak, de nem mindig. Sokszor a keresett szerep távol helyezkedett el a függőségi fában a célszótól, gyakran a mondat másik felében. És olyan is volt, hogy a szintaktikai kapcsolat alapján várt helyen nem a keresett szerep volt. Ez utóbbi gyakran a szintaktikai elemző hibájából adódott. Így a feladat a függőségi fában a célszótól távolabbi szerepek megkeresése és a közelebbi hamis pozitív jelöltek kiszürése volt.

\section{Kapcsolódó munkák}

A szemantikus szerepek címkézése napjainkban a természetes nyelvfeldolgozás (NLP) egyik legdinamikusabban fejlődő területe. Angol nyelvű szövegekre sok módszer született már, ezek általában konstituensfa alapú szintaktikailag elemzett mondatokat használnak, és mondat szinten vizsgálják az eseményeket.

Kezdetben az SRL munkákban csak igékkel foglalkoztak, az igéket önállóan vizsgálták és általános szerepeket kerestek (például Agent, Patient, Instrument). A PropBank korpusz [13] szövegeit használták fel, amiben angol nyelvü szövegekhez vannak kiemelt igék annotálva a hozzájuk tartozó szemantikus szerepekkel. A 2004-es és 2005-ös CoNNL feladatokban foglalkoztak ezzel a témával $[2,4]$.

Később az igéket már nem önállóan vizsgálták, hanem tématerületenként csoportosították azokat (keretek). Az általános szerepek mellett már vizsgáltak domén-specifikus szerepeket is. Ehhez a FrameNet korpusz [7] szövegeit használták fel, amiben angol nyelvü szövegek vannak szemantikus szerepek szerint annotálva. Ezek is elsősorban igékkel foglalkoznak, de keresnek nem igei cél-szavakra is. Egy fontos alaptanulmányt készített D. Gildea és D. Jurafsky [8] az SRL témában. A Senseval-3 task [11] egyik része is a FrameNet-re alapozott SRL feladat volt. Az ACE program is más NLP feladatok mellett SRL témával is foglalkozik [1].

Xue és társa [19] a jelöltek számának csökkentésére mutatott be egy módszert. A jelöltek számát jelentősen csökkentették, miközben a fedést magasan tartották. 
Koomen és társai [10] és Toutanova és társai [18] a szerepek azonosítása után a szerepek közötti kapcsolatokkal, függőségekkel foglakoztak. Azt vizsgálták, hogy a megtalált kifejezések hogyan lehetnek együtt a célszónak a szerepei.

Surdeanu és társai [17] és Pradhan és társai [14] számos SRL alapú rendszer kimenetét kombinálták egy rendszerbe.

Carreras és társai [2,3] és Surdeanu és társai [17] munkáiban, ha egy mondaton belül több célszó található, akkor ezeket nem csak egymástól függetlenül kezelték, hanem közös szerepeket is kerestek hozzájuk.

Johansson és társa [9] angol nyelvű szövegekre a konstituens alapú elemzés helyett függőségi elemzést használt.

Szemantikus szerepek címkézésére magyar nyelvű szövegekre is készültek már munkák. Farkas és társai [3] a szemantikuskeret-illesztésre szabály alapú módszert használtak. Mi gépi tanulásos módszert alkalmaztunk ugyanerre. A szabályalapú módszerrel ellentétben a gépi tanulásos módszer nem igényel annyi erőforrást és elö-feldolgozást, és automatikusan alkalmazható más doménekre is. Ehmann és társai [4] pszichológiai témájú szövegeken szemantikus szerepek címkézésénél csak két általános szerepet keresnek: az ágens és a recipiens szerepeket (cselekvő, elszenvedő). Mi a vállalatfelvásárlások kereten belül nem csak a két általános szerepet, hanem több domén-specifikus szerepet is címkéztünk. A következő szerepeket vizsgáltuk: Vevő, Eladó, Áru, Ár, Idő. Csak az igei és fönévi igenévi célszavak szerepeit kerestük.

Az angol nyelvű szövegekre általában konstituensfa alapú szintaktikailag elemzett mondatokat használnak. Az elöző pontban ismertetett okok miatt mi a magyar nyelvü szövegeinkre függőségi fákkal dolgozó elemzőt használtunk a Magyarlanc programcsomag segítségével [20].

\section{Szemantikus keretek és a szemantikus szerepek}

Sok információkinyerő rendszer manapság tárgykör (domén) specifikus keretekkel dolgozik. Egy-egy tárgykör eseményeit célszerü egy kereten belül vizsgálni, hiszen ugyanazok a szerepek tartoznak minden eseményhez, ami egy adott csoporthoz tartozik. Például egy repülőjegy foglalásokat feldolgozó rendszer a következő szerepeket használhatja: indulási időpont, érkezési időpont, célállomás, indulási állomás, távolság, ár. Az előző rendszer célszavai lehetnek például: foglal, lefoglal, előjegyez, vált. Ha a célszavakat önállóan dolgozzuk fel, akkor csak kevés tanító adattal tudunk dolgozni. A célszavak keretekben történő csoportositása jelentősen csökkenti ezt a problémát, hiszen a több célszó tanító adatai összeadódnak.

Munkánkban a vállalati vásárlások, tulajdonváltozások keretével foglalkoztunk, igei és főnévi igenévi célszavakhoz kerestük ki a szereplőket. A következő igei célszavakat vizsgáltuk meg az adott kereten belül: vesz, vásárol, szerez, bekebelez, gyarapít, ad, átruház, értékesít, forgalmaz. Valamint e célszavak minden igekötős, módbeli és időbeli változatát is. A célszavakhoz a mondatokon belül a következő szerepeket kerestük meg: vevő, eladó, áru, ár, idő.

Példák a szerepekre a vállalati vásárlások tárgykörben. A példákban vastag betüvel vannak kiemelve a célszavak és szögletes zárójelben a szerepek találhatóak. Alsóindexben szerepel az adott szerep típusa.

[A svéd Electrolux] Eladó eladja [motorgyártó részlegét]Áru [az olasz Appliance Components Companies részvénytársaságnak]vevö - tájékoztatott az Electrolux.

[A Deutsche Börse AG]vevö pénteken bejelentette, hogy teljesen megveszi [a luxemburgi Clearstream elszámolóházat]

A példákban látszik, hogy egy szerep általában több szóból áll és a mondatok általában nem tartalmazzák mind az öt szerepet.

\section{Felhasznált korpusz és programcsomagok}

\subsection{Felhasznált Korpusz}

Az alkalmazásunk teszteléséhez a Szeged Korpusznak a rövidhírek csoportjának egy olyan változatát használtuk fel, amelyikben annotálva vannak a vállalati vásárlásokra a szemantikus 
szerepek. Ezek közül 1000 mondatot használtunk fel. A tanításhoz és kiértékeléshez 10-szeres keresztvalidációt alkalmaztunk.

\subsection{Felhasznált programcsomagok}

A feladatokat bináris osztályozásra vezettük vissza. Az osztályozáshoz a Weka programcsomagnak $^{1}$ a J48-as döntési fa elemzőjét használtuk fel. A Weka adatbányászati feladatokhoz készített gépi tanuló algoritmusok gyüjteménye. A feladathoz felhasználtuk még a Magyarlanc 2.0 programcsomagot is. [20] A csomag magyar szövegek mondatra és szavakra bontására, a szavak morfológiai elemzésére, majd szófaji egyértelmüsítésére, és mondatok függőségi nyelvtan szerinti szintaktikai elemzésére alkalmazható.

Egy tipikus adatbányászati szoftver architektúráját láthatjuk az 1. ábrán:

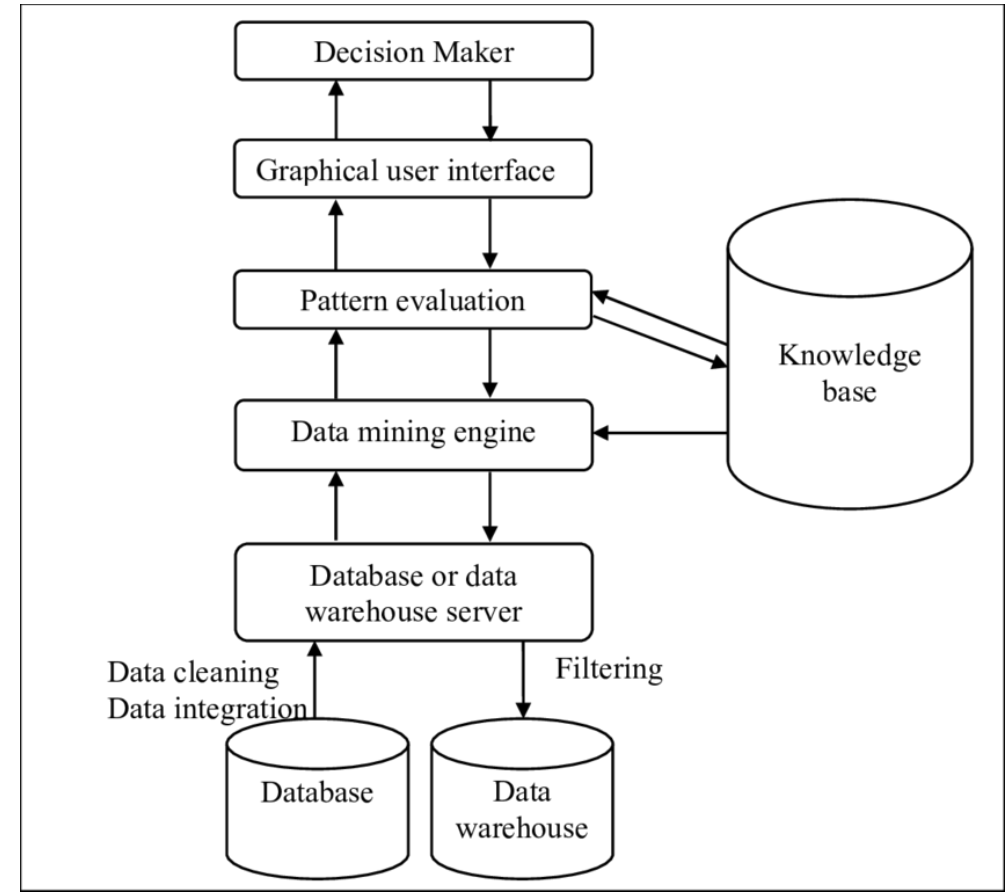

1. ábra. Egy tipikus adatbányászati szoftver architektúrája forrás: https://www.researchgate.net

\section{Magyarlanc programcsomag elemzésének bemutatása}

A Magyarlanc a bemenetére érkező mondatoknak elkészíti az előző pontban leírt elemzését. A mondat minden szavához külön sorba elkészíti az elemzést (2. ábra). Minden szóról megadja a következő információkat: sorszám, szó, lemma, szófaj, morfológiai kódok. A sor végén megadja, hogy az adott szó melyik szóval van szintaktikai kapcsolatban, és hogy milyen a kapcsolat típusa. A szintaktikai kapcsolatok alapján a mondatok egy függőségi fát alkotnak.

Az elemzés után megjelenítettük vizuális elemzővel a szintaktikai kapcsolatok alapján a mondat függőségi fáját a program online elemzőjével ${ }^{2}$ (3. ábra). Az elemzés és a vizuális ábrázolás egymásnak megfelelően megadja a szavak közötti szintaktikai kapcsolatokat.

Példa:

A Deutsche Börse AG pénteken bejelentette, hogy teljesen megveszi a luxemburgi Clearstream elszámolóházat.

\footnotetext{
${ }^{1}$ http://www.cs.waikato.ac.nz/ml/weka/

2 http://www.inf.u-szeged.hu/rgai/magyarlanc-service/
} 


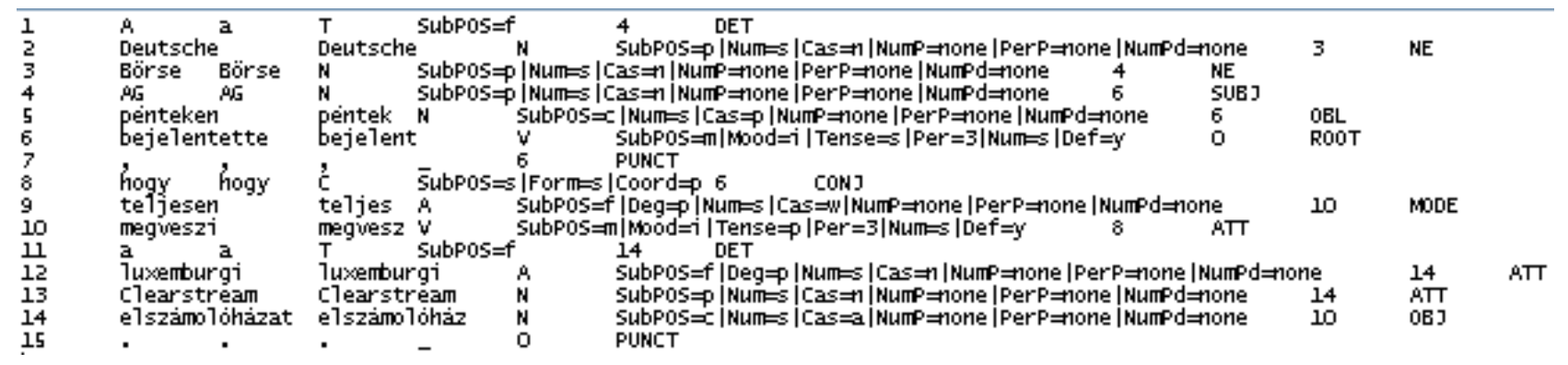

2. ábra. A Magyarlanc programcsomag elemzése

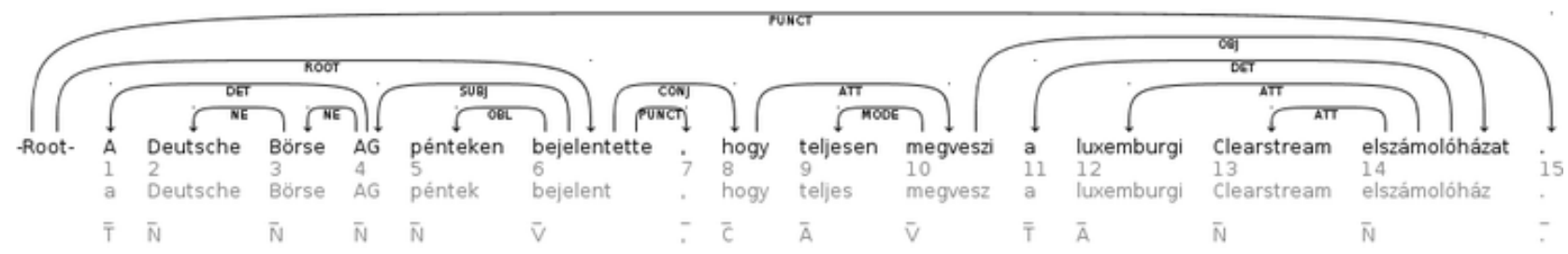

\section{3. ábra. A mondat függőségi fája}

Az elemzésekből látszik, hogy a függőségi elemző egy szabályos elemző fát készít. $A$ fa legfelső eleme a Root. A fa csomópontjaiban vannak a mondat szavai, az ágak a szavak közötti szintaktikai kapcsolatokat reprezentálják. A fában kiemelt szerepe van az igéknek. A föige (a példákban a bejelentette) általában a Root alatt helyezkedik el, a szintaktikai kapcsolatokon keresztül ehhez kapcsolódnak a többi elemek.

Ha a szerep több szóból áll, akkor ezek a szavak egy részfát alkotnak a mondat fáján belül. A részfa a kiemelt szaván (fejszó, headword) keresztül kapcsolódik a fa többi részéhez.

Van, amikor a szerep kiemelt szava (headword) a célszóhoz kapcsolódik közvetlenül. Ilyen esetben könnyebb megtalálni a szerepet. Van, amikor a szerep kiemelt szava nem a célszóhoz kapcsolódik közvetlenül. A példamondatnál a vevő kiemelt szava (AG) nem kapcsolódik szintaktikailag a megveszi célszóhoz az elemzőfában, hanem a bejelentette igén keresztül. Ilyenkor nehezebb megtalálni a szerepet. Minél közelebb van a szerep a célszótól a mondaton vagy az elemzőfán belül, annál nagyobb a valószínűsége a szerep azonosításának.

Bár a Magyarlanc program elkészíti a mondatoknak a szintaktikai elemzését, de a példákon is láttuk, hogy a szintaktikai kapcsolat típusából nem következik a szemantikai szerep. Például a vesz célszónak az alanya a vevő, az elad célszónak az alanya az eladó. Így a szintaktikai kapcsolatok mellett több más tulajdonságot is meg kell figyelni a mondatban. A feladatot megnehezíti, hogy a Magyarlanc elemző is hibával dolgozik, így ez a hiba és a hibákból eredő hamis döntések megjelennek a mi eredményeinkben is. Jobb eredményeket kaptunk volna, ha szövegeink kézzel lettek volna annotálva ezen szempontok szerint.

\section{Az osztályozás bemutatása}

A célszavakhoz a következő szerepeket vizsgáltuk: vevő, eladó, áru, ár, idő. Minden bemeneti mondatnál adott volt a célszó. A feladat az adott szerep megkeresése volt.

Az osztályozóknál a jelöltek a függőségi elemzőfa csomópontjai voltak. Egy mondaton belül általában egy csomópont a keresett szerep kiemelt szava (head word). Az osztályozásnál ezek a true esetek, a többi csomópont pedig a false eset.

Az osztályozáshoz bináris osztályozót használtunk. Az osztályozó az adott mondatnál bejelöli a keresett szerepet. Az osztályozónak nem adtuk meg, hogy az adott mondat tartalmazza-e az adott szerepet, vagy sem. Voltak olyan mondatok is, amelyek nem tartalmazták a keresett szerepet. (1. táblázat)

A kiértékelésnél szigorú szabályt alkalmaztunk: csak azt a döntést fogadtuk el, amelyik pontosan az annotált szerepet jelöli meg. Sem az ezt tartalmazó fákat, sem ennek a részfáit nem fogadtuk el pozitív döntésnek. Ha ennél enyhébb szabályt alkalmaznánk, akkor magasabb eredményeket kapnánk. 


\subsection{Jellemzőkészlet}

A tanító és a kiértékelő halmazon a jelöltekhez jellemzőket vettünk fel. Az SRL feladatokban használt általános jellemzőket [8] mi is alkalmaztuk. Ezeken kívül újakkal is kibővítettük a jellemzőkészletünket. Ehhez felhasználtuk a függőségi elemzőfát is, a jelölt és a célszó viszonyát a függőségi fában, mert ez gyakran egy fontos tulajdonsága az adott szerepnek.

A jelöltekhez a következő jellemzöket választottuk ki:

Felszíni jellemzők: Bigramok, trigramok: A vizsgált szavak végén lévő 2-es, 3-as betűcsoportok. Pozíció: a jelölt a célszó előtt vagy után áll a mondatban. Távolság-mondatban: a jelölt és a célszó szótávolsága a mondaton belül.

Morfológiai jellemzők: Mivel a magyar nyelv igen gazdag morfológiával rendelkezik, ezért számos morfológiaalapú jellemzőt definiáltunk. Jellemzőként definiáltuk az eseményjelöltek MSD-kódját felhasználva a következő morfológiai jegyeket: típus(SubPos), mód(Mood), eset(Cas), idő(Tense), személy(PerP), szám(Num), határozottság(Def). Szófaj, Lemma: a jelölt és a célszó szófaja és lemmája.

Jellemzők az elemzőfa alapján-1: Ide azokat a jellemzőket soroltuk, amelyeket az SRL feladatokhoz általában felhasználnak [8]. A jelölt és a célszó viszonyát vizsgáltuk a függőségi elemzőfában. Mindkettő egy-egy csomópont az elemzőfában. Szófaj-útvonal: Egymás után írtuk a jelölt és a célszó közötti csomópontok szófaját, feljegyezve azt is, hogy az elemzőfában felfelé, vagy lefelé haladtunk az adott kapcsolatnál. Például: $\mathrm{C} \uparrow \mathrm{S} \uparrow \mathrm{V} \uparrow \mathrm{C} \uparrow \mathrm{V} \uparrow \mathrm{V} \downarrow \mathrm{V} \downarrow N \downarrow N \mathrm{~N} \downarrow A$. Uralkodó-kategóriaszófaja: A jelölt és a célszó közötti útvonalon megkerestük a legmagasabban fekvő csomópontot, és feljegyeztük a hozzá tartozó szó szófaját.

Jellemzők az elemzőfa alapján-2: Itt az egyéni, új jellemzőket soroltuk fel. Jelölt-célszótávolság-elemzőfában: A jelölt és a célszó csomópontjai közötti csomópontok száma az elemzőfában. Lemma-útvonal: Mint a Szófaj-útvonal, de itt a jelölt és a célszó között végigmenve a csomóponti szavak lemmáját jegyeztük fel. Például:

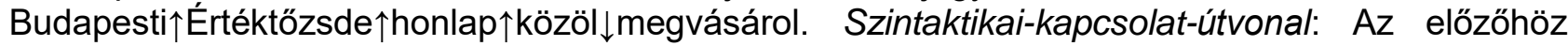
hasonlóan itt azt vettük fel, hogy a jelölt és a célszó között az elemzőfában milyen szintaktikai kapcsolatokon keresztül tudunk eljutni. Például: $\uparrow C O O R D^{*} S U B J \downarrow A T T \downarrow I N F \downarrow O B J \downarrow A T T$. Jelölt-alattirészfában-van-e-névelem: A Magyarlanc program az elemzésében jelöli, ha talált névelemeket a mondatban. Mivel a vállalati tulajdonváltozások témakörében gyakran találkozunk vállalati névelemekkel, ezért felvettük, hogy a jelölt, vagy az alatta levő részfa tartalmaz-e névelemet? Jelöltalatti-részfában-névelem-távolság: az elözőhöz hasonlóan megadtuk a részfában azt a mélységet, ahol először találtunk névelemet.

Az osztályozás leírása: Minden szerephez külön osztályozót készítettünk. Minden osztályozó esetén a tanító és a kiértékelő halmazon minden jelölthez felvettük a bemutatott jellemzőket. Ezen jellemzők kialakításához felhasználtuk a korpusz mondatainak kézi annotációját és az elemzőfák által adott elemzéseket. A tanító halmaz jelöltjeit és a hozzájuk kigyűjtött jellemzőket beolvastuk az osztályozóba a gépi tanításhoz. Az osztályozó a jellemzők alapján megismerte és megtanulta a „rejtett összefüggéseket” és szabályokat alakított ki. A kiértékelésnél a tanított osztályozó elemezte a kiértékelő halmaz mondatait, amelyekkel eddig nem találkozott. Az elemzés során minden jelölthöz bejelölte, hogy az adott szerephez tartozónak tartja vagy nem.

\subsection{Statisztikai arány felhasználása az osztályozásnál}

A jelöltekhez a jellemzőket két módszer alapján választottuk ki. Első módszernél az előző részben bemutatott alapjellemzőket használtuk fel. Második módszernél az alapjellemzők helyett a tanító adatokon a jellemzőkészletből számított statisztikai arányokat használtuk fel: a tanító halmaz alapján megszámoltuk minden jellemző esethez, hogy hány alkalommal fordult elö és ebből hányszor volt a jelölt pozitív. Ezek alapján kiszámítottuk a hozzá tartozó pozitív-arányt. Például ha a Jelölt-lemma jellemzőnél a jelölt-lemma = Corp. eset 11-szer fordult elő és ebböl 7-szer volt pozitív eset (4-szer pedig negatív), akkor hozzá a 0,64-es pozitívarány tartozott. Ebben az esetben az osztályozónak a jelöltekhez nem az alap-jellemzőt, hanem a hozzá tartozó arányt adtuk meg. Az előző példánál Jelölt-lemma-arány $=0,64$. Ezzel jelentősen csökkentettük az osztályozó vektorterének méretét az első módszerhez képest és így a futási időt is. Ez a kidolgozási időszakban hasznos volt. Harmadik esetben az előző két módszer jellemzőit együtt használtuk fel. 
A statisztikai-arány jellemzők hatása az osztályozás eredményére. Megvizsgáltuk, hogy az előzőleg bemutatott statisztika-arány jellemzők hogyan befolyásolják az osztályozási eredményeinket. Elöször az osztályozást lefuttattuk csak a statisztikai-arány jellemzökkel, majd csak az alapjellemzőkkel és végül a két jellemzőcsoporttal együtt. Volt, amikor a statisztikai-arány eset önállóan jobban teljesített, mint az alapjellemzőkkel eset önállóan. Volt, amikor fordítva. De a legjobb eredményt akkor kaptuk, amikor az alapjellemzőket és a statisztikai arány jellemzőket együtt használtuk.

\subsection{Vektortér méretének csökkentése}

A vektortér méretét csökkentettük a következő módszerrel: csak azokat a jellemzőelőfordulásokat vettük fel az osztályozáshoz, amelyek a tanító halmazon legalább háromszor szerepeltek. Ezzel jelentősen csökkentettük a futási időt és csak az osztályozás szempontjából jelentéktelen jellemző-előfordulásokat hagytuk ki.

\subsection{Célszavak csoportosítása a kereten belül}

Először a modell viselkedését egy gyakori célszóra önállóan néztük meg. Ehhez a vásárol célszót választottuk ki.

Majd a célszavakat csoportosítottuk. A vásárlásokkal kapcsolatos mondatoknál a vevő és az eladó szerepek viselkedését meghatározza, hogy az adott célszónál az alany általában vevő vagy eladó. Ezért a célszavakat két csoportra bontottuk a következő egyszerü módszerrel. A vevőcentrikus csoportba azok a szavak kerültek, amelyeknél az alany általában a vevő: vesz, vásárol, szerez, bekebelez, gyarapít. Az eladó-centrikus csoportba pedig azok, amelyiknél az alany általában az eladó: ad, átruház, értékesít, forgalmaz. Ez a felosztás segítette a vevő és az eladó szerepek megtalálását. Egy harmadik esetben pedig nem végeztünk csoportosítást.

\subsection{Baseline mérések}

A Baseline módszereket a döntési fa legfontosabb feltételei alapján állítottuk össze. Azokat a jelölteket vettük pozitívnak, amelyekre teljesül: Az Áru szerepnél azokat, amelyek tárgy (OBJ) szintaktikai kapcsolatban vannak a célszóval. Az Ár szerepnél azokat, amelyeket egy előre elkészített pénznemek lista tartalmazott. Az Idő szerepnél azokat, amelyeket a következö lista tartalmazott: évszámok 1990-2014-ig, hónapnevek, napnevek, sorszámok 1-31-ig.

A vevő-centrikus célszavaknál a Vevő szerepnél és az eladó-centrikus célszavaknál az Eladó szerepnél azokat, amelyek alany (SUBJ) kapcsolatban vannak a célszóval. A vevő-centrikus célszavaknál az Eladó szerepnél azokat, amelyek végén a következő trigramok állnak: tól, től, ból, ből. Az eladó-centrikus célszavaknál a Vevő szerepnél azokat, amelyek részes eset (DAT) kapcsolatban vannak a célszóval. A következő eredményeken látni fogjuk, hogy gépi tanulási modell jóval felülteljesítette a Baseline modellünket.

\subsection{Statisztikai adatok}

Mondatok száma összesen: $1000 \mathrm{db}$

Azon mondatok száma, amelyek tartalmazzák az adott szerepet:

A fontosabb statisztikai adatokat a következő táblázat tartalmazza (1. táblázat): 
1. Táblázat. Statisztikai adatok (db)

\begin{tabular}{|l|l|l|l|l|l|l|}
\hline \multicolumn{1}{|c|}{ Célszavak } & $\begin{array}{c}\text { Mondatok } \\
\text { száma }\end{array}$ & Vevö & Eladó & Áru & \multicolumn{1}{|c|}{ Ár } & Idő \\
\hline kiemelt: vásárol & 265 & 263 & 107 & 276 & 104 & 99 \\
\hline Vevő-centrikus & 548 & 531 & 222 & 573 & 214 & 208 \\
\hline Eladó-centrikus & 452 & 261 & 374 & 459 & 82 & 115 \\
\hline csoportosítás nélkül & 1000 & 783 & 579 & 1025 & 299 & 312 \\
\hline
\end{tabular}

Az osztályozónak nem adtuk meg, hogy az adott mondat tartalmazza-e az adott szerepet, vagy sem. (Az Áru szerep azért nagyobb, mint a mondatok száma, mert volt olyan mondat, ahol több áru szerepelt.)

\section{Eredmények}

\subsection{Baseline mérések eredményei}

A Baseline mérések eredményeit a következő táblázatban láthatjuk (2. táblázat):

2. Táblázat: Baseline mérések eredményei

\begin{tabular}{|l|l|l|l|}
\hline \multicolumn{1}{|c|}{ Szerep } & Pontosság & Fedés & F-mérték \\
\hline Vevő-centrikus célszavak & & & \\
\hline Vevő & 48,24 & 59,73 & $\mathbf{5 3 , 3 7}$ \\
\hline Eladó & 54,77 & 72,13 & $\mathbf{6 2 , 2 6}$ \\
\hline Áru & 73,25 & 73,25 & $\mathbf{7 3 , 2 5}$ \\
\hline Ár & 67,33 & 96,02 & $\mathbf{7 9 , 1 6}$ \\
\hline Idő & 34,74 & 57,89 & $\mathbf{4 3 , 4 2}$ \\
\hline Eladó-centrikus célszavak & & & \\
\hline Vevő & 78,18 & 44,10 & $\mathbf{5 6 , 3 9}$ \\
\hline Eladó & 42,63 & 47,50 & $\mathbf{4 4 , 9 3}$ \\
\hline Áru & 77,47 & 72,97 & $\mathbf{7 5 , 1 5}$ \\
\hline Ár & 62,64 & 93,44 & $\mathbf{7 5 , 0 0}$ \\
\hline Idő & 23,95 & 46,51 & $\mathbf{3 1 , 6 2}$ \\
\hline
\end{tabular}

\subsection{Eredmények a vásárol kiemelt célszóra}

A vásárol célszóra az eredményeket a következő táblázatban láthatjuk (3. táblázat):

3. Táblázat: Eredmények a vásárol kiemelt célszóra (\%)

\begin{tabular}{|l|l|l|l|}
\hline \multicolumn{1}{|c|}{ Szerep } & Pontosság & Fedés & F-mérték \\
\hline Vevő & 69,88 & 49,77 & $\mathbf{5 7 , 6 3}$ \\
\hline Eladó & 82,10 & 60,30 & $\mathbf{6 8 , 7 0}$ \\
\hline Áru & 80,72 & 77,11 & $\mathbf{7 8 , 7 0}$ \\
\hline Ár & 90,38 & 83,02 & $\mathbf{8 5 , 7 8}$ \\
\hline Idő & 78,75 & 52,82 & $\mathbf{6 1 , 2 7}$ \\
\hline Átlag: & 80,37 & 64,60 & $\mathbf{7 0 , 7 1}$ \\
\hline
\end{tabular}

\subsection{Eredmények a vevő-centrikus célszavakra}

A vevő-centrikus célszavakra az eredményeket a következő táblázatban láthatjuk (4. táblázat): 


\section{Táblázat: Eredmények a vevő-centrikus célszavakra (\%)}

\begin{tabular}{|l|l|l|l|}
\hline \multicolumn{1}{|c|}{ Szerep } & Pontosság & Fedés & F-mérték \\
\hline Vevő & 76,01 & 57,33 & $\mathbf{6 5 , 0 9}$ \\
\hline Eladó & 79,57 & 66,15 & $\mathbf{7 1 , 5 8}$ \\
\hline Áru & 79,18 & 80,93 & $\mathbf{7 9 , 9 4}$ \\
\hline Ár & 87,78 & 80,07 & $\mathbf{8 2 , 4 7}$ \\
\hline Idő & 83,13 & 63,89 & $\mathbf{7 1 , 2 6}$ \\
\hline Átlag & 81,13 & 69,67 & $\mathbf{7 4 , 0 7}$ \\
\hline
\end{tabular}

A 3. és a 4. táblázat eredményeit összehasonlítva látható, hogy ha a hasonló viselkedésű célszavakat egy csoportban kezeltük, akkor majdnem minden esetben jobb eredményeket értünk el, mint ha a célszavakat önállóan vizsgálnánk. Ennek oka, hogy a több célszó több mondatot és jelöltet ad meg és a több jelölt jellemzőiböl általánosabb szabályokat tudott készíteni az osztályozó. A modell legjobban az Ár és az Áru szerepekre, leggyengébben pedig a Vevő szerepre teljesített.

\subsection{Eredmények az eladó-centrikus célszavakra} táblázat):

Az eladó-centrikus célszavakra az eredményeket a következő táblázatban láthatjuk (5.

5. Táblázat: Eredmények az eladó-centrikus célszavakra (\%)

\begin{tabular}{|l|l|l|l|}
\hline \multicolumn{1}{|c|}{ Szerep } & Pontosság & Fedés & F-mérték \\
\hline Vevő & 74,59 & 66,82 & $\mathbf{7 0 , 1 3}$ \\
\hline Eladó & 68,97 & 48,51 & $\mathbf{5 6 , 3 5}$ \\
\hline Áru & 85,92 & 82,16 & $\mathbf{8 3 , 6 4}$ \\
\hline Ár & 83,64 & 63,87 & $\mathbf{7 1 , 5 8}$ \\
\hline Idő & 76,38 & 51,78 & $\mathbf{5 9 , 8 6}$ \\
\hline Átlag & 77,90 & 62,63 & $\mathbf{6 8 , 3 1}$ \\
\hline
\end{tabular}

Az eladó-centrikus esetben a modell legjobban az Ár és az Áru szerepekre, leggyengébben pedig az Eladó szerepre teljesített.

\subsection{Eredmények a célszavak csoportosítása nélkül}

A célszavak csoportosítása nélküli esetre az eredményeket a következő táblázatban láthatjuk (6. táblázat):

6. Táblázat: Eredmények a célszavak csoportositása nélkül (\%)

\begin{tabular}{|l|l|l|l|}
\hline \multicolumn{1}{|c|}{ Szerep } & Pontosság & Fedés & F-mérték \\
\hline Vevő & 76,93 & 60,11 & $\mathbf{6 7 , 0 5}$ \\
\hline Eladó & 72,04 & 50,39 & $\mathbf{5 9 , 1 3}$ \\
\hline Áru & 83,62 & 80,24 & $\mathbf{8 2 , 0 1}$ \\
\hline Ár & 88,47 & 76,26 & $\mathbf{8 1 , 7 7}$ \\
\hline Idő & 85,44 & 64,53 & $\mathbf{7 3 , 1 4}$ \\
\hline Átlag & $\mathbf{8 1 , 3 0}$ & $\mathbf{6 6 , 3 1}$ & $\mathbf{7 2 , 6 2}$ \\
\hline
\end{tabular}

A célszavak csoportositásától azt vártuk volna, hogy a Vevő-centrikus cél-szavaknál a Vevő szerepre, az Eladó-centrikus célszavaknál pedig az Eladó szerepre jobb eredményt kapunk, mint a csoportosítás nélküli esetben. Ez az Eladó szerepre nem teljesült. Ennek egyik oka, hogy az Eladócentrikus mondatokban az Eladó szerep sokszor távolabb volt a célszótól az elemzőfában. Másik oka, hogy a Vevő-centrikus célszavaknál az Eladó szerepre jó eredményt kaptunk (71,58-es F- 
mérték) a JeloltVegenBigram és a JeloltVegenTrigram jellemzök hatására. Ez a jó eredmény javította erősen a csoportosítás nélküli esetben is az Eladó szerep eredményét. Így a jobb eredményt a csoportosítás nélküli esetre kaptunk (72,62-es F-mérték).

\subsection{Az eredmények összehasonlítás a kapcsolódó munkákkal.}

Angol nyelvü szövegekre Gildea és társa [8] sok keretre és azokon belül sok szerepre végezték el a feladatot. Elsősorban igékkel foglalkoznak, de keresnek nem igei célszavakra is. Ezek átlagolt eredményére 63\%-os $\mathrm{F}$ mértéket kaptak. Eredményeink (72,62\% F-mérték átlag) jónak számítanak annak ellenére, hogy mi csak egy keretet és ahhoz csak öt fö-szerepet vizsgáltunk, és csak igei és fönévi igenevekhez kerestünk szerepeket.

\section{Összegzés}

Munkánkban bemutattunk gazdag jellemzőtéren alapuló gépi tanuló megközelítésünket, amely automatikusan képes magyar nyelvü szövegekben szemantikus szerepek címkézésére függőségi elemző alkalmazásával. A vállalati vásárlások, tulajdonváltozások keretével foglalkoztunk. Ezen a kereten belül 1000 annotált mondatot dolgoztunk fel és a következő szerepeket kerestük: Vevö, Eladó, Áru, Ár, Idő. Jellemzőkészletünkben felszíni, morfológiai és a függőségi elemzés alapján kinyert jellemzőket használtunk fel. Ezen alapjellemzőket kiegészítettük a jellemzőkből számolt statisztikai arányokkal is. Megvizsgáltuk, hogy a statisztikai jellemzők hogyan befolyásolják a modell hatékonyságát. Megvizsgáltuk, hogy a modell hogyan teljesít egy gyakori célszóra önállóan, és a célszavak keretekbe összefoglalt csoportjára is. A mérésekhez célszavainkat csoportosítottuk több szempont szerint. Bár munkánkban a vizsgált szövegek kevesebb témát fedtek le, mint az angol nyelvü szövegekre bemutatott munkák, de eredményeink jónak számítanak a bemutatott angol munkák eredményeivel összehasonlítva.

\section{Köszönetnyilvánítás}

Köszönettel tartozunk a kutatás támogatásáért, amely az EFOP-3.6.1-16-2016-00006 „A kutatási potenciál fejlesztése és bővitése a Neumann János Egyetemen" pályázat keretében valósult meg. A projekt a Magyar Állam és az Európai Unió támogatásával, az Európai Szociális Alap társfinanszírozásával, a Széchenyi 2020 program keretében valósul meg.

\section{Irodalomjegyzék}

[1] D. Ahn: The stages of event extraction. Proceedings of the ARTE '06 Proceedings of the Workshop on Annotating and Reasoning about Time and Events, (2006) 1-8

[2] X. Carreras, L. Màrquez: Introduction to the CoNLL-2004 shared task: semantic role labelling. CONLL '04 Proceedings of the Ninth Conference on Computational Natural Language Learning, (2004) 152-164

[3] X. Carreras, L. Marquez, G.Chrupała: Hierarchical recognition of propositional arguments with perceptrons. In Proceedings of the Eighth Conference on Computational Nat-ural Language Learning (CoNLL-2004), Boston, MA., $106-109$

[4] X. Carreras, L. Màrquez: Introduction to the CoNLL-2005 shared task: semantic role labelling. CONLL '05 Proceedings of the Ninth Conference on Computational Natural Language Learning, (2005) 89-97

[5] Ehmann B., Lendvai P., Miháltz M., Vincze O., László J.: Szemantikus szerepek a narratív kategoriális elemzés (NARRCAT) rendszerében. IX. Magyar Számítógépes Nyelvészeti Konferencia, Szeged, 2013, p. 121-123

[6] Farkas R:, Konczer K., Szarvas Gy.: Szemantikus keret illesztés és az IE-rendszer automatikus kiértékelése. II. Magyar Számítógépes Nyelvészeti Konferencia (2004). Szeged, Szegedi Tudományegyetem, 49-53.

[7] C.L. Fillmore, J.Ruppenhofer, C.F. Baker: Framenet and representing the link between semantic and syntactic relations. In Churen Huang and Winfried Lenders, editors, Frontiers in Linguistics, volume I of Language and Linguistics Monograph Series B.Institute of Linguistics, Academia Sinica, Taipei (2004) 19-59.

[8] D. Gildea, D. Jurafsky: Automatic labelling of semantic roles. Computational Linguistics Journal, Volume 28 Issue 3 , September 2002, (2002) 245-288

[9] R. Johansson, P.Nugues: Semantic structure extraction using nonprojective dependency trees. In Proceedings of the 4th International Workshop on Semantic Evaluations (SemEval-2007), Prague, Czech Republic, 227-230

[10] P. Koomen, V. Punyakanok, D. Roth, W.Yih: Generalized inference with multiple semantic role labelling systems. In Proceedings of the Ninth Conference on Computational Natural Language Learning (CoNLL-2005), Ann Arbor, MI., $181-184$ 
[11] K. C. Litkowski: SENSEVAL-3 TASK: Automatic Labelling of Semantic Roles. Proceedings of SENSEVAL-3, the Third International Workshop on the Evaluation of Systems for the Semantic Analysis of Text (2004)

[12] L. Márquez, X. Carreras, K.C. Litkowski and S. Stevenson: Semantic Role Labelling: An Introduction to the Special Issue. Computational Linguistics 34(2), (2009) 145-159.

[13] M. Palmer, D. Gildea, P. Kingsbury: The Proposition Bank: An annotated corpus of semantic roles. Computational Linguistics, 31(1):71-105. (2005)

[14] S. Pradhan, K.Hacioglu, W.Ward, J.H. Martin, D.Jurafsky: Semantic role chunking combining complementary syntactic views. In Proceedings of the Ninth Conference on Computational Natural Language Learning (CoNLL2005), Ann Arbor, MI., 217-220

[15] Z. Subecz: Detection and Classification of Events in Hungarian Natural Language Texts. Proceedings of the 17th International Conference, TSD 2014, Brno, Czech Republic (2014) Springer Lecture Notes in Computer Science Volume 8655, 2014, pp 68-75

[16] Subecz Z, Nagyné Cs.É..: Igei események detektálása és osztályozása magyar nyelvű szövegekben. X. Magyar Számítógépes Nyelvészeti Konferencia, Szeged, (2014) 237-247

[17] M. Surdeanu, L. Marquez, X. Carreras, P.R.Comas: Combination strategies for semantic role labelling. Journal of Artificial Intelligence Research (JAIR), 29:105-151. (2007)

[18] K. Toutanova, A.Haghighi, C.Manning: Joint learning improves semantic role labelling. In Proceedings of the 43rd Annual Meeting of the Association for Computational Linguistics, Ann Arbor, MI. (2005) 589-596

[19] N. Xue, M.Palmer: Calibrating features for semantic role labelling. In Proceedings of the Conference on Empirical Methods in Natural Language Processing (EMNLP), Barcelona, Spain. 88-94

[20] Zsibrita J., Vincze V., Farkas R.: magyarlanc 2.0: szintaktikai elemzés és felgyorsított szófaji egyértelműsítés. IX. Magyar Számítógépes Nyelvészeti Konferencia, Szeged, (2013) 368-374 